\title{
EARLY STAGES OF ARCHAEOLOGICAL STUDY OF THE KASHKADARYA OASIS
}

\author{
Nilufar Rajabova
}

Associate Professor, Department Of World History, Karshi State University, Uzbekistan

\section{ABSTRACT}

The article analyzes the first stages of studying the archaeological sites of the Kashkadarya oasis from a historical point of view. Beginning in the 18th century, Europeans began to record information about the Kashkadarya oasis. Their main focus is on highlighting the lifestyle of the population, as well as information on historical monuments. In particular, in memoirs, reports and brochures, A. Burns, N. Khannykov, V.V. Bartold, N. Maev, V. Krestovsky, B. Litvinov, D. Logofet, A. Validov, I. Kastane, L. Zimin, you can get a lot of information on this topic. Despite this, the first studies were mostly brief. Most importantly, the attention of architects and art critics is focused on the history of architectural structures in Shakhrisabz, built during the reign of Amir Temur and the Temurids. However, attempts to shed light on the history of the cities of Karshi and Shakhrisabz based on written sources consisted in a collection of the first archaeological observations, historical artifacts and manuscripts.

Noteworthy is the information written by N. Khannykov, V.V. Bartold, N. Mayev. Subsequent studies also made extensive use of their memoirs. B. Litvinov's information about the Kashkadarya oasis was supplemented by his drawings. According to Logofet, the history of the city of Shakhrisabz is emphasized, and archaeological excavations show that its history goes back two thousand years.

D. Logofet pays great attention to the medieval history of Karshi, cites various historical sources.

It is important for I.Kastana and L.Zimin to describe the archaeological monuments preserved in the vicinity of Karshi from the point of view of that period and compare them on the basis of ancient and medieval written sources.

KEYWORDS: - Kashkaraya oasis, archaeology, Karshi, Shakhrisabz, European sources, orientalist, Abdullakhan, Takhta-Karacha pass, Kalai Zakhaki Moron, Shullyuk-tepa, Nakhsheb, Amir Temur, Temurids.

\section{INTRODUCTION}

In the history of archeology, attention to historiographic topics has increased in recent years. Of course, the study of the formation of archaeological science is of particular importance in history.

Uzbekistan is a country of the richest history and culture, captured in written historical sources and in monuments of material culture - from primitive sites to the ruins of cities and settlements, outstanding examples of architecture dating back many millennia and included in the golden fund of the country's cultural heritage, many of which are masterpieces of world culture. According to preliminary data of scientists, today on the archaeological map of the republic it is possible to single out more than 5 thousand monuments of different eras.

The priority goal of studying these monuments 
CURRENT RESEARCH JOURNAL OF HISTORY 2(7): 26-33, July 2021

DOI: https://doi.org/10.37547/history-crjh-02-07-06

ISSN 2767-472X

(C)2021 Master Journals

\section{Crossref do) 11 Google}

Accepted 23 $3^{\text {th }}$ July, 2021 \& Published 28thJuly, 2021

is, in our opinion, the reconstruction of the historical past of the peoples of Uzbekistan on the basis of the study of material traces of human activity through systematic, purposeful field archaeological research and scientific processing of the accumulated materials.

Along with the specific study of the region's monuments, one of the urgent tasks for today is the historiographic generalization of the studies of this region. As noted by the famous historian of Central Asia B.V. Lunin, and we agree with him, historiography helps to answer the question "what was done, by whom and how, what was covered well enough and correctly, and what is weaker, and what the researchers still have to do" [1].

\section{Main ParT}

The study of the archaeological sites of Kashkadarya is part of the general study of the archaeological heritage of Central Asia and the level of knowledge of the region should be presented against the background of general archaeological work in the Central Asian Mesopotamia.

Kashkadarya region is located in the south-west of Uzbekistan. In the north, it is bounded by the Zarafshan ridge, in the east and south by the forts of the Gissar ridge, and in the west by the Karshi sandy steppe.

Many Western travelers and ambassadors visited the Kashkadarya Valley, as evidenced by European sources. Among the first and most extensive descriptions of the Kashkadarya region by European travelers is the book by A. Burns (Borns), widely known at the time.

He was a Lieutenant in the East India Company and a Fellow of the Royal Society of Great Britain. A. Burns was sent to find out the most convenient ways to collect information about Central Asia. Having visited Karshi, A. Burns writes that "... Karshi, which lay 60 miles south of Samarkand, is an oasis formed by a river flowing from the neighboring region of Shahr-Sabza and depleted from the fertilization of this district ...". Between Karshi and Oks, he notes several separate hills, which, in his opinion, are the remains of dwellings: "The country north of Oks is inhabited by shepherd tribes and not at all cultivated; but the remains of water pipes and other structures, especially between Karshi and Bukhara, testify to a happier century in these now abandoned lands" [2].

Thus, the books about his travels written by A. Burns captivatingly attracted the attention of wide readership of the countries of Western Europe and Russia.

In 1841-1842 yy. orientalist N.V. Khanykov spent eight months in Bukhara, which resulted in his well-known and well-deserved recognition of his work dedicated to the Bukhara Emirate. He described Karshi as a city consisting of three parts: a citadel, an old city and a new city. He gave a description of the city gates, mosques, the old bridge built by Abdullakhan across the Kashkadarya River. N.Khanykov calls Karshi the second capital city in the emirate after Bukhara, writes about the presence of a permanent garrison in it. The traveler left evidence of the presence of archaeological monuments in the vicinity of Karshi [3].

According to V.V. Bartold, "the exceptional merits of N.V. Khanykov is even more surprised if we remember that the author was a little over 20 years old during his stay in Bukhara. V.V. Bartold called "Description of the Bukhara Khanate" a classic work of a historical and geographical character. O. A. Sukhareva noted that the work of N.V. Khanykova, "executed for her time at a great scientific height, has not lost its significance for our days" [4].

of the subsequent early researchers of Kashkadarya, it is necessary, of course, to note 
CURRENT RESEARCH JOURNAL OF HISTORY 2(7): 26-33, July 2021

DOI: https://doi.org/10.37547/history-crjh-02-07-06

ISSN 2767-472X

(C)2021 Master Journals

\section{Crossref do) 81 Google}

Accepted 23th July, 2021 \& Published 28thJuly, 2021

N.A. Maev is a famous Russian historian, ethnographer, journalist, geographer, explorer of Central Asia. From 1870 he worked in Tashkent; in 1870 - 1892 was the first editor of "Turkestanskie vedomosti", and in 1872 - 1874 editor of the collections "Materials for statistics of the Turkestan region". On the N.A. Mayev was one of the organizers of the first local history museum and public library in Tashkent. In 18711872 and in 1874-1878 he went to inspect the paths to the Amu Darya, in 1872 he was seconded to the south of the Bukhara Emirate, in order to study the geography of the Gissar region and the Kulyab bek state. He described a mountain range, into which the wide Fergana, Zerafshan valleys and Shakhrisabz, TakhtaKaracha pass, on the road from Samarkand to Kitab, rise 5,180 feet $(1,788 \mathrm{~m})$. The lowering of the Tien Shan was noted as it approached the Guzar and the banks of the Amu Darya, the Akrabat pass, the highest point of the massif of 4,590 feet absolute height, which was interrupted by the road from Karshi to Shirabad. During the trip, N.A. Maev studied hydrography and hydronyms of the region. The Gissar expedition led by N.A. Maeva received significant geographical materials necessary for further, including archaeological research.

In 1874 N.A. Mayev makes a trip to Shakhrisabz, which he perceived as a city - the birthplace of Amir Temur, ancient Kesh. He paid special attention to the architectural monuments, among which the ruins of Aksaray were most of all interested: "The luxurious palace of Timur Aksaray now presents only ruins, like all Bukhara buildings of this era. But these ruins are striking even now with their original beauty. From the south side, traces of the dome that crowned the entire building are clearly visible; this dome has now collapsed, leaving only two high walls, decorated with tiled mosaics and inscriptions".

He describes Karshi as a city connecting the
Bukhara oasis with the Shakhrisabz and Gissar ones: "Due to its happy position, Karshi has become an important transit point for the huge Bukhara market. Everything that goes to Bukhara from the east and south - east will not escape Karshi ..." [5]. For the first time among the visitors N.A. Mayev noted the sardoba, which was located on the south side of the city. He also left a description of the provinces. For the first time he comes across information about the villages of Kasan (today a district), Kasbi (today a district), Yabi, Kitay, which still exist.

In 1878, a number of messages appeared on the pages of the Turkestanskie vedomosti newspaper, which were devoted to N.A. Maev to study the paths to the Amu Darya. These are: 1) the road to Darbent, Shirabad and crossings through the Amu Darya, Karakamar and Kelif; 2) the road from Kelif between the mountains, directly to Guzar. N.A. Maev was the first of the Europeans who went along these directions [6]. During a trip through Guzar, he examined the mountain path leading from the Tenga-Haram tract to the large and prosperous village of Kuytan, through the Akbash pass and along the Kerchakdarya valley [7].

In general, in the works of N.A. Maev contains a significant amount of information on geographical, ethnographic, archaeological and architectural plans, which later served as important material for travelers and specialists interested in the Kashkadarya oasis.

In December 1882, the city of Karshi and Shakhrisabz was visited by an official for special assignments under the Turkestan GovernorGeneral, writer V.V. Krestovsky. In Shakhrisabz, he examined the monuments that were built during the reign of Temur and Temurids [8]. An important detail is contained in the description of his trip in January 1883 in the vicinity of Karshi, when the traveler visited the ruins of an ancient city called Shulluk. This allows V.V. 
CURRENT RESEARCH JOURNAL OF HISTORY 2(7): 26-33, July 2021

DOI: https://doi.org/10.37547/history-crjh-02-07-06

ISSN 2767-472X

(C)2021 Master Journals

\section{Crossref do) 81 Google}

Accepted 23 ${ }^{\text {th }}$ July, 2021 \& Published 28thJuly, 2021

Krestovsky, the discoverer of this archaeological site. Everyone who came to Karshi after him certainly visited Shulluktepa, which, as it was later established, is the ruins of the medieval city of Nasaf.

Visited in 1895 and 1910 in Karshi, the officerartist B.N. Litvinov noted that the city was one of the most profitable regions for the Bukhara Emirate, in the past Karshi was connected by excellent caravan routes with all the main points of the region - with Bukhara, Samarkand, Termez through Guzar, with Balkh and Herat through Kerki [9]. Having studied the surroundings of the city, he also described Shulluktepa: “... We must not forget that modern Karshi has moved somewhat to the south-west from the old habitat. Of course, the present Karshi also has more than half a thousand years of its existence; but ancient Nakhsheb, old Karshi, was on the site of a natural boundary called Shullyuk-tepa by the natives. It was a vast hill with clear and grandiose traces of the past ..." [10].

Much of what B.N. Litvinov, later repeated in one of his books border guard officer D.N. Logofet, which visited Karshi in the first decade of the XX century. He drove from Samarkand to Shakhrisabz, Yakkabag and Karshi through the Takhta-Karacha pass and left many notes about the architectural and archaeological monuments of the region.

D.N. Logofet paid considerable attention to history, noting that the city of Kesh or Shakhrisabz was one of the main cities of the land of Ostrushany (from the point of view of D.N. Logofet - N.R.). In the notes of D.N. Logofet contains information about archaeological sites in the vicinity of Shakhrisabz - an ancient fortress 25 versts from Shakhrisabz, near the village of Yartepa and in the village of Tashkurgan.

Having visited Yakkabag, I noted its fortress and several burial mounds in the vicinity. The researcher suggested that Yakkabag, which arose in the period before the Christian era, was for a long time one of the points in which Parsism (the outdated definition of Zoroastrianism - N.R.) firmly developed, which then only after a long and stubborn struggle gave way to Buddhism, in turn ousted by Nestorian Christianity, and then already absorbed almost without a trace by Islam. D.N. Logofet wrote that: "... the repeatedly destroyed and re-emerging city and fortress of Yakkabag stood on the remnants of their former life, covered with a thick layer of earth. Archaeological surveys and excavations could provide great material for illuminating the past of this place, which existed for almost 2 thousand years".

In Shakhrisabz, the researcher described four gates: Darvaze Agenin, Darvaze Abdulakh, Darvaze Kasabon and Darvaze Sharistan, and under the administrative institutions, he noticed a prominent hill below them - archaeological remains. In general, during a trip to the upper regions of Kashkadarya, D.N. Logofet tried to pay attention to all aspects of the life of the region: geography, history, ethnography and archeology.

The same applies to his trip to the western part of Kashkadarya, where he described, located on a hilly plain and having the appearance of an ancient Muslim city of Karshi, that the area was a hilly plain. At the end, which opens before them Karshi, the second most important city of the Bukhara Khanate, considered almost equal to the capital in its historical past. This city, which appeared more than two thousand years ago, was called Nakh-Sheba, being the main trade point from Bukhara to Balkh. Having survived a long era of the Greco-Bactrian civilization, he subsequently, with the appearance of the Uzbeks on the plains of Central Asia, turned into one of the important strongholds of the new rulers. In 1318, the Chagatai prince Kebek built a fortress in it, and since then Nakh-Sheb, having lost its important name, became known under the name 
CURRENT RESEARCH JOURNAL OF HISTORY 2(7): 26-33, July 2021

DOI: https://doi.org/10.37547/history-crjh-02-07-06

ISSN 2767-472X

(C)2021 Master Journals

\section{Crossref dof 81 Google}

Accepted 23th July, 2021 \& Published 28thJuly, 2021

Karshi, that is, a castle or a fortress. D.N. Logofet noted that Karshi was widely spread on both sides of the high-water Kashkadarya River and was connected by several bridges; Urda was fortified with a brick wall with towers, all buildings in the center were enclosed in a fortress wall with several gates overlooking the main streets, near which there were high towers with guards to guard the entrances. He did not disregard the political and ethnic ties of the region's population with other cities and regions, and described the handicrafts of Karshi.

D.N. Logofet notes that the modern city was built southwest of the place where ancient Nachsheb was. Not being an archaeologist, he could not identify the remains of the fortress built by Kebekhan in the relief of Karshi. This led him to the conclusion about the localization of the city of this time on the site of the settlement of Kalai Zahoki Moron. Describing Shulluktepa, he noted that the locals almost all the time were engaged in excavating various things in the form of utensils and coins [11].

In general, it should be emphasized that D.N. Logofet was the first researcher who visited the Kashkadarya valley to pay such great attention to the archaeological sites located on its territory.

After the creation of the Turkestan circle of archeology amateurs, the Kashkadarya Valley at first was not of great interest to its members. In 1914 A.D.Validov was sent by the Russian Committee to study Central and East Asia and the Imperial Academy of Sciences to Bukhara to collect information about local collections of manuscripts. Expecting to stay in the Bukhara Khanate for several months, he decided to visit more and more important cities.

In Bukhara, he bought one manuscript about Temur in the amount of 75,000 tenge. In Shakhrisabz A.Z. Validov meets with many people who had expensive manuscripts at their disposal. He also drew attention to the monuments of the Temurid period, which had tiled inscriptions in Arabic. In Guzar and Karshi, he also collected a large number of manuscripts. A. Validov noted that in Karshi, Mullah Najmiddin preserved all the works of Mawlian Hussein ulVoiz Kashifi, a contemporary of Sultan Hussein Baykara [12].

In 1916, a member of the Turkestan circle of archeology amateurs I.A. Castanie began route trips to the archaeological sites of the Karshi oasis. He noted a large number of kurgans located in rings around the city of Karshi and stretching in dense rows along the cultural strip of the Kashkadarya valley. Their total number and enormous size amazed the researcher's imagination.

Several versts from the city, at the very railway station, he noted an ancient fortress of impressive size, known as Kalai Zahoki Moron. He drew up a schematic plan of the fortress, "consisting of three quadrangles, separated by two deep ditches: the outer quadrangle is about 1000 steps on each side, the height of the first rampart is up to 3 sazhens, the width of the rampart on top is one and a half sazhens ...

In the center, at the highest point there was a citadel where traces of excavations of treasure hunters were noted".

I.A. Kastanie and his companion N. Goloshevich counted about 54 kurgans - tepa along the railway from the fortress Kalai Zakhoki Moron to Kasan station, and three versts to the station, a large tepa was noted in the steppe (Shullyuktepa fortress - N.R.) [13].

I.A. Castagnie was the first researcher to try to connect the information of ancient authors with archaeological sites on the territory of Kashkadarya. Near the city of Karshi, he localized Nautaka, where the Macedonians captured Bess, and where Alexander the Great spent the winter. The researcher believed that Kebek built the city 
CURRENT RESEARCH JOURNAL OF HISTORY 2(7): 26-33, July 2021

DOI: https://doi.org/10.37547/history-crjh-02-07-06

ISSN 2767-472X

(C)2021 Master Journals

\section{Crossref dof 80 Google}

Accepted 23th July, 2021 \& Published 28thJuly, 2021

on the site of modern Karshi, and the Kalai Zakhaki Moron fortress was built by Amir Temur and dated back to the XIV-XV centuries.

Although, most of the archaeological sites in the region underwent only a superficial examination (without exact sizes and dates), nevertheless, I.A. Castagnier left a significant amount of information on its archeology and ancient history.

Another member of the Turkestan and TransCaspian circles of archeology amateurs, orientalist L.A. Zimin together with the photographer P.M. Nikiforov visited the Karshi oasis in late May - early June 1916. He visited the settlement of Shulluktepa, which, in his opinion, was first encountered in the literature of the 18th century. Knowing very well the medieval sources, L.A. Zimin noted the coincidence of their information with the modern topography of the settlement: the location of the city on both sides of the river and the absence of the walls of the shahristan and expressed the opinion that Nessef and Nakhsheb are one city that was located in the lower part of the Kashkadarya River before the conquest of Mavaraunnahr by the Arabs, and then and later [14].

Another object of observation L.A. Zimin was the settlement of Kalai Zakhoki Moron. According to his notes, it was a typical remnant of a fortress like Kalai Dabus. Just like I.A. Castagnier, L.A. Zimin claimed that Amir Temur built the fortress.

In 1927, his article on the history of the city of Karshi was published, in which archaeological sites, including Shulluktepa, were described in detail. He was the first of the researchers who noted the palace of Kazankhan "Zandzhirsaray", burned down in 1387 by the troops of Tokhtamysh. He also mentioned a large settlement in the middle of the steppe (Yerkurgan - N.R.).

Analyzing ancient sources, he concluded that the path from Bactria to Sogdiana had to pass through the Kashkadarya valley. He argued that it was here that one should look for Nautaka, mentioned by historians describing the campaign of Alexander the Great. As I.A. Castanier, he localized this city in the Karshi oasis. L.A. Zimin was the first to draw on Chinese sources, in which the names of ancient and medieval cities located in the Kashkadarya valley - Tsi-shek and Nashebo, respectively Kesh and Nakhshab were encountered [15]. In Karshi and its environs, L.A. Zimin took many photographs and several sketches.

Of particular importance in terms of attracting written sources, for comparison with archaeological and topographic data, are the classic works of Academician V.V. Barthold. On their basis in the Kesh region, he allocated 16 rustak volosts for the Middle Ages and cities such as Subakh, Naukad-Kureish, Iskifagn, Bazda and Kasba with the approximate location of these cities: Subakha - on the site of the present Guzar, Iskifagna - on the site of the village of Karabag, and Bazdy and Kasby - in the lower reaches of the Kashkadarya [16].

V.V. Bartold visited the Kashkadarya valley several times. Together with the archaeologist V.L. Vyatkin, he was sent to Shakhrisabz to clarify the information of A.L. Kun on the construction of the Kuk Gumbaz madrasah by Shahrukh. The researchers managed to read the inscription on the portal, which mentioned $839 \mathrm{AH}$. and the name of Ulugbek, which allowed them to come to the conclusion about the construction of the Kuk Gumbaz madrasah not by Shakhrukh, but by Ulugbek [17]. Another task - to clarify the location of the graves of Bakhadyr Taragay and Zhahangir, the father and son of Amir Temur, could not be solved due to the short duration of the trip. Despite the fact that V.V. Bartold did not directly study the archaeological sites in the Kashkadarya valley, but his work in archaeological and topographic terms has not 
CURRENT RESEARCH JOURNAL OF HISTORY 2(7): 26-33, July 2021

DOI: https://doi.org/10.37547/history-crjh-02-07-06

ISSN 2767-472X

(C)2021 Master Journals

\section{Crossref do) 81 Google}

Accepted 23 ${ }^{\text {th }}$ July, 2021 \& Published 28thJuly, 2021

lost its significance to this day. Undoubtedly, the greatest contribution of V.V. Bartold in the study of the ancient history of Kashkadarya is the proposed localization of cities and large villages on the trade routes from Bukhara to Merv and Balkh. His hypotheses were later confirmed during stationary work. The works of this researcher-orientalist made it possible to present a general picture of the historical events that took place after the conquest of Central Asia by the Arabs and Mongols, as well as during the reign of Amir Temur and the Temurids.

An important direction in the study of antiquities in the Kashkadarya valley in the first decades of the XX century was the study of architectural monuments of Shakhrisabz, which aroused the greatest interest of architects and art critics.

\section{Conclusion}

As for the archaeological study of the Kashkadarya valley during these years, they should be characterized as the systematic collection and registration of local information and objects. Until the 20s of the XX century inclusive, archaeological events, even when carried out by central organizations, were mostly random episodes. Their topics, differing in some narrowness and archeological approach, as a rule, depended on the interests of individuals.

\section{ReFERENCES}

1. Лунин Б.В. Историография и источниковедение в Узбекистане: состояние и задачи // Общественные науки в Узбекистане. - 1981. - № 2. - С. 33.

2. Бёрнс А. Путешествие в Бухару. - М.: 1854. - C. 224.
3. Ханыков Н.В. Описание Бухарского ханства. - СПб.: 1843. - С. 44-45, 50.

4. Лунин Б.В. История Узбекистана в источниках. Узбекистан в сообщениях путешественников и ученых (20-80-е годы XIX в.). - Т.: Фан, 1990. - С. 71.

5. Маев Н.А. Очерки Бухарского ханства. T.: $1875 .-$ C. 82.

6. Известия // Туркестанские ведомости. 1878, - № 24, 20 июня.

7. Известия // Туркестанские ведомости. 1878, - № 35, 5 сентября.

8. Крестовский В.В. В гостях у эмира Бухарского. - СПб.: 1887. - С. 43.

9. Литвинов Б.Н. Карши // Туркестанские ведомости. - 1910, - № 114, 25 мая.

10. Литвинов Б.Н.Карши // Туркестанские ведомости. - 1910, - № 116, 27 мая.

11. Логофет Д.Н. В горах и на равнинах Бухары. - СПб.: 1913. - С. 522.

12. Валидов А. О собраниях рукописей в Бухарском ханстве // Записки Восточного отделения Императорского Русского археологического общества. Т. 23. - СПб., 1916. - С. 246-247.

13. Кастанье И.А. Археологическая разведка в западных частях Бухары // Протоколы Туркестанского кружка любителей археологии (ниже ПТКЛА). Вып. 4. - Т.: 1917. - С. 26-30.

14. Зимин Л.А. Краткий отчёт о поездке по Бухаре в 1916 г. // ПТКЛА. - Т.: 1916. C. $103-104$.

15. Зимин Л.А. Нахшеб. Несеф. Карши. Их история и древности // В.В. Бартольду. Туркестанские друзья, ученики и почитатели. - Т.: 1927. - С. 197-199.

16. Бартольд В.В. Туркестан в эпоху 
CURRENT RESEARCH JOURNAL OF HISTORY 2(7): 26-33, July 2021

DOI: https://doi.org/10.37547/history-crjh-02-07-06

ISSN 2767-472X

(C)2021 Master Journals

Crossref dof 81 Google

Accepted 23th July, 2021 \& Published 28thJuly, 2021

монгольского нашествия / Сочинения.

- М.: изд-во Восточной литературы, 1963. Т. 1.

17. Центральный государственный архив Республики Узбекистан, ф-95, оп. 1, д. 374, л. 4-5. (Краткий отчёт В.В. Бартольда о поездке в Самарканд, Бухару, Шахрисабз в 1925 г. с 27.07 до 9.08.).

18. Khalimovich, O. N., Rasuljanovna, I. N., \& Shakarovich, G. I. (2020). The Purpose and Outcome of Diplomatic Missions in the II-I Centuries Between Central Asia And China. Journal of Critical Reviews, 7(9), 126-128. 